\title{
Die Entstehung des negativen Melanchthonbildes
}

\author{
Protestantische Melanchthonkritik bis 1560
}

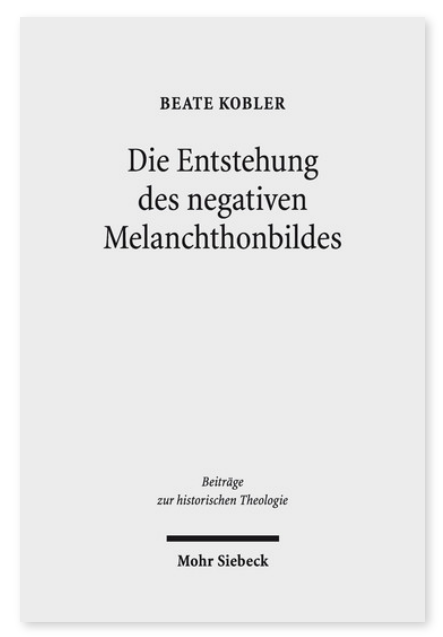

2014. XXVI, 623 Seiten. BHTh 171

ISBN 978-3-16-152697-8

DOI 10.1628/978-3-16-152697-8

eBook PDF 159,00€

ISBN 978-3-16-152696-1

Leinen $159,00 €$
Der Theologe, Humanist und Reformator Philipp Melanchthon wurde im Lauf der vergangenen Jahrhunderte immer wieder negativ beurteilt, und es bildeten sich zahlreiche Klischees heraus. Ihm wurde beispielsweise vorgeworfen, er habe die Lehre Luthers verdorben und verraten; zudem wurde er als ängstlich und allzu nachgiebig charakterisiert. Beate Kobler setzt dieses negative Bild voraus und widmet sich der Frage, wann und wie es zu Melanchthons Lebzeiten entstand, im Zuge welcher Ereignisse es sich verfestigte und welche Kritiker es in besonderer Weise beeinflussten. Dabei legt sie den Schwerpunkt auf die protestantische Kritik. Diese ist besonders interessant, da sie dem faktischen Einfluss und der besonderen Bedeutung Melanchthons entgegensteht. Im Ergebnis zeigt sich, dass das negative Melanchthonbild weitaus früher entstand, als bisher angenommen wurde.

Beate Kobler Geboren 1972; Studium der Ev. Theologie und Altphilologie (Latein) in Tübingen und Bonn; 2000 1. Kirchliches Examen; 2012 Promotion; seit 2013 Pfarrerin an der Martinskirche in Sindelfingen.
Jetzt bestellen:

https://mohrsiebeck.com/buch/die-entstehung-des-negativen-melanchthonbildes-9783161526978?no_cache=1 order@mohrsiebeck.com

Telefon: +49 (0)7071-923-17

Telefax: +49 (0)7071-51104 